\title{
POLITIK HUKUM LINGKUNGAN HIDUP DI INDONESIA BERDASARKAN UNDANG-UNDANG NOMOR 32 TAHUN 2009 TENTANG PERLINDUNGAN DAN PENGELOLAAN LINGKUNGAN HIDUP
}

\section{Politics Law Environment in Indonesia by Law Number 32 of 2009 on the Protection and Environmental Management}

\author{
Dani Amran Hakim \\ Universitas Diponegoro, Semarang \\ email: daniamranhakim@yahoo.com
}

\begin{abstract}
The legal political environment in Indonesia in terms of protection, management and control of environmental pollution in Indonesia and to investigate the implementation of environmental pollution control and law enforcement in Indonesia. the results of the study stated that the renewal law of Environmental management is influenced by a variety of development changes occurring in society, such as the influence of the era of democratization, industrialization, advancement of science and technology and the rise of the welfare demands of various parties. Political aspects contained in the politics of Law Number 32 of 2009 on the protection and management of the environment has not been run in accordance with the legal political objective, because there are natural resources that can not be utilized for the prosperity and welfare of the people. It is also still a lot of water pollution, air pollution, deforestation and other actions of the parties who damage the environment. It is necessary to implement environmental management to preserve the environment and develop skills which are harmonious, consistent and balanced in order to support the implementation of the development of environmentally sustainable. Law enforcement agencies in understanding the perceived environmental legal system are still experiencing difficulties. Lack of understanding of the law enforcement officers will cause rules is formed in one unified national legal system will deviate from the direction of the political objectives of the law. The need for clear law enforcement for the doer / destroyer of the environment in order to create a deterrent effect and between 3 penalties (criminal, civil and administrative) is not overlapping. Law enforcement difficult because of the difficulty of proving and determining the standard criteria of environmental damage.
\end{abstract}


Keywords: Legal Politic, Environment, The Act Number 32 years 2009 on The Protection and Environmental Management

\begin{abstract}
abstrak
Politik hukum lingkungan di Indonesia dalam hal perlindungan, pengelolaan dan pengendalian pencemaran lingkungan hidup di Indonesia serta untuk mengetahui pelaksanaan pengendalian pencemaran lingkungan hidup dan penegakan hukumnya di Indonesia. Hasil penelitian tersebut menyatakan bahwa pembaharuan undang-undang pengelolaan Lingkungan Hidup dipengaruhi oleh berbagai perkembangan perubahan yang terjadi di dalam masyarakat seperti misalnya pengaruh era demokratisasi, industrialisasi, kemajuan ilmu pengetahuan dan teknologi dan semakin maraknya tuntutan kesejahteraan dari berbagai pihak. Aspek politik yang dikandung dalam politik hukum Undang-Undang Nomor 32 tahun 2009 tentang Perlindungan dan Pengelolaan Lingkungan Hidup belum berjalan sesuai dengan tujuan politik hukumnya, karena sumber daya alam yang ada belum dapat dipergunakan untuk sebesar-besarnya kemakmuran dan kesejahteraan rakyat. Selain itu juga masih banyak terjadi pencemaran air, polusi udara, pembalakan hutan dan perbuatan lain para pihak-pihak yang merusak lingkungan. Maka perlu melaksanakan pengelolaan lingkungan hidup untuk melestarikan dan mengembangkan kemampuan lingkungan hidup yang serasi, selaras dan seimbang guna menunjang terlaksananya pembangunan yang berkelanjutan yang berwawasan lingkungan hidup. Penegak hukum dalam memahami sistem hukum lingkungan dirasakan masih mengalami kesulitan. Kurangnya pemahaman para aparat penegak hukum akan menimbulkan tatanan yang terbentuk dalam satu kesatuan sistem hukum nasional akan menyimpang dari pada arah tujuan politik hukum. Perlunya penegakan hukum yang jelas bagi para pelaku/perusak lingkungan hidup agar menimbulkan efek jera dan di antara 3 sanksi (pidana, perdata dan administrasi) tersebut tidak adanya tumpang tindih. Penegakan hukum sulit dilakukan oleh karena sulitnya pembuktian dan menentukan kriteria baku tentang kerusakan lingkungan.
\end{abstract}

Kata Kunci: Politik Hukum, Lingkungan Hidup, Undang-Undang Nomor 32 tahun 2009 tentang Perlindungan dan Pengelolaan Lingkungan Hidup

\title{
A. Pendahuluan
}

Pengendalian dan pengelolaan lingkungan hidup terkait erat dengan kesejahteraan rakyat suatu negara. Melalui pengendalian dan pengelolaan lingkungan hiduplah (di mana sumber daya alam ada di dalamnya) kesejahteraan rakyat hendak diwujudkan. Bagi negara yang mengklaim 
sebagai negara kesejahteraan (welfare state), menjadikan kesejahteraan rakyat sebagai tujuan negara atau hidup bernegara. Segala aktivitas penyelenggaraan negara diorientasikan pada upaya mencapai dan memenuhi kesejahteraan rakyat tersebut.

Selama lebih dari satu dasawarsa masalah-masalah yang berkenaan dengan pencemaran lingkungan hidup manusia telah mendapatkan perhatian yang sangat serius dari masyarakat internasional. Masalah-masalah seperti ledakan penduduk, meningkatnya jumlah kaum miskin, menderasnya arus urbanisasi, terlantarnya tanah-tanah pedesaan, dan pembangunan industri yang tidak mengindahkan ketahanan sumber-sumber daya alam telah memprihatikan banyak kalangan seperti kaum politisi, intelektual, tokohtokoh masyarakat, dan para kritisi pembangunan. Dalam berbagai kesempatan pertemuan internasional rasa prihatin yang sangat beralasan itu sempat dituangkan ke dalam deklarasi-deklarasi ${ }^{1}$ politik penting yang dapat dipandang sebagai kritik terhadap gaya-gaya pembangunan yang tidak mempedulikan tuntutan-tuntutan keseimbangan ekologis. ${ }^{2}$ Dalam perkembangannya sampai hari ini pun paradigma pembangunan yang berkelanjutan yang dideklarasikan oleh para kaum politisi, kaum intelektual, dan pemerhati lingkungan di dunia tersebut tidak dijalankan sesuai dengan apa yang telah disepakati bersama-sama tersebut bisa dibilang mengalami kegagalan. itu bisa dilihat dari kerusakan lingkungan (dampak dari gas rumah kaca, semakin panasnya bumi, dan perubahan iklim) yang terjadi diseluruh dunia termasuk di Indonesia.

Berdasarkan pembukaan Undang-Undang Dasar Negara Kesatuan Republik Indonesia Tahun 1945 secara eksplisit dinyatakan bahwa salah satu tujuan pendirian negara dan pembentukan pemerintahan negara adalah untuk memajukan kesejahteraan umum. Untuk mencapai kesejahteraan umum tersebut, UUD 1945 memberikan kepada negara hak ekslusif untuk menguasai lingkungan hidup dan sumber daya alam, yang dalam literatur hukum dikenal dengan hak menguasai negara. Integrasi lingkungan hidup dan sumber daya alam, hak menguasai negara dan kesejahteraan rakyat sebagaimana tertuang dalam Pasal 33 ayat 3 UUD 1945 yang menyatakan bahwa "Bumi, air dan kekayaan alam yang terkandung didalamnya dikuasai oleh negara dan dipergunakan sebesar-besarnya untuk kesejahteraan rakyat".

\footnotetext{
${ }^{1}$ Salah satu deklarasi tersebut ialah Tahun 1992 merupakan puncak dari proses politik, yang akhirnya pada Konferensi Tingkat Tinggi (KTT) Bumi di Rio de Janerio, Brazil (1992), KTT Pembangunan Berkelanjutan di Johannesburg (2002) paradigma pembangunan berkelanjutan diterima sebagai sebuah agenda politik pembangunan untuk semua negara di dunia. Lihat juga A. Sonny Keraf, , Etika Lingkungan Hidup, (Jakarta: Kompas, 2010), hlm. 190.

${ }^{2}$ Abdul Hakim G. Nusantara, Politik Hukum Indonesia, (Jakarta: Yayasan Lembaga Bantuan Hukum Indonesia Cetakan Pertama, 1988), hlm. 131.
} 
Muhammad Hatta menerjemahkan hak menguasai negara sebagai hak negara untuk membuat aturan guna melancarkan kehidupan ekonomi. ${ }^{3}$

Berdasarkan hak menguasai negara tersebut, negara Indonesia telah menetapkan berbagai kebijakan dan regulasi sebagai guidance dan legal baseline dalam pengelolaan lingkungan dan sumber daya alam dalam rangka mewujudkan kesejahteraan rakyat. Dalam kenyataannya, pengelolaan lingkungan hidup di Indonesia masih menghadapi problem yang sama yaitu adanya benturan antara berbagai peraturan perundang-undangan, terutama antara undang-undang sektoral terkait sumber daya alam (yang lebih berorientasi pada pemanfaatan sumber daya ekonomi dan undang-undang lingkungan hidup (yang dianggap terlalu menekankan pada aspek perlindungan lindungan hidup). Akibatnya, pengelolaan dan pengendalian lingkungan hidup di bawah kontrol pemerintah melalui ketentuan peraturan perundang-undangan sebagai umbrella provision belum mampu mencapai tujuan pengelolaan lingkungan hidup, terwujudnya kelestarian fungsi lingkungan hidup dan tercapainya kesejahteraan rakyat.

Untuk menjamin adanya kepastian hukum agar masyarakat memunyai kesadaran untuk turut serta dalam melestarikan lingkungan mereka, pemerintah telah menyiapkan perangkat hukum khususnya hukum lingkungan untuk menjerat para pencemar dan perusak lingkungan hidup. Undang-Undang yang dimaksud adalah Undang-Undang Nomor 4 Tahun 1982 tentang Lingkungan Hidup (UULH ) serta Undang-Undang Nomor 23 Tahun 1997 tentang Pengelolaan Lingkungan Hidup (UUPLH) dan telah disempurnakan dengan Undang-Undang yang terbaru yaitu Undang-Undang Nomor 32 Tahun 2009 tentang Perlindungan dan Pengelolaan Lingkungan Hidup (UUPPLH). Keberadaan undang-undang ini diharapkan dapat menjadi bahan acuan bagi aparat penegak hukum untuk menindak pihakpihak yang telah sengaja atau tidak sengaja telah melakukan pencemaran lingkungan. Para penegak hukum dapat menyelesaikan kasus-kasus tindak pidana lingkungan yang terjadi, khususnya masalah pencemaran air oleh limbah industri yang sering marak terjadi terutama di kota-kota besar.

Praktik Good Environmental Governace ${ }^{4}$ dalam beberapa tahun ini di Indonesia menjadi sorotan publik. Kerusakan lingkungan dan menurunnya

\footnotetext{
${ }^{3}$ Roeslan Abdulgani, Aktualisasi Pemikiran Bung Hatta tentang Demokrasi Ekonomi dalam Sri Edi Swasono, Bung Hatta Bapak Kedaulatan Rakyat, (Jakarta: Yayasan Hatta, 2000), hlm. 262-263, sebagaimana dikutip oleh Mujibussalim, Perlindungan Hukum Terhadap Sumber Daya Alam Berkaitan Dengan Peraturan Perlindungan Hutan Dalam Pelaksanaan Otonomi Daerah, Disertasi, (Bandung: Universitas Padjadjaran, 2008), hlm. 89-90.

${ }^{4}$ Good Governance menurut UNDP (United Nations Development Programme) adalah suatu konsensus yang dicapai oleh pemerintah, warga negara, dan swasta bagi penyelenggaraan pemerintah dalam suatu negara. Dalam banyak hal Good Governance diartikan sebagai tata kelola pemerintahan yang baik. Elemen dasar dari Good Governance adalah pembangunan yang keberlanjutan, kaitannya di sini dalam keberlanjutan pembangunan maka perlu
} 
kualitas lingkungan seringkali dihubung-hubungkan bahkan sering dinyatakan bahwa penyebabnya adalah adanya Environmental Governace yang tidak sesuai dengan peraturan perundang-undangan yang semestinya. Kondisi ini sebagai akibat dari penyelengaraan corporate governance yang tidak memenuhi standar pengelolaan suatu institusi atau perusahaan.

Penyimpangan ini ditandai dengan lemahnya penegakan hukum, pengadilan yang tidak mandiri, dan budaya KKN dalam aparatur birokrasi, dan kurang maksimalnya peran masyarakat. ${ }^{5}$ Dalam penjelasan umum UUPLH dinyatakan bahwa lingkungan hidup yang baik dan sehat merupakan hak asasi dan hak konstitusional bagi setiap warga negara Indonesia. Oleh karena itu, negara, pemerintah, dan seluruh pemangku kepentingan berkewajiban untuk melakukan perlindungan dan pengelolaan lingkungan hidup dalam pelaksanaan pembangunan berkelanjutan agar lingkungan hidup Indonesia dapat tetap menjadi sumber dan menunjang hidup bagi rakyat Indonesia serta makhluk hidup lain.

Maka dari itu politik hukum lingkungan dalam penerapannya di Indonesia bertujuan untuk melindungi serta mengelola lingkungan hidup dengan baik. Dengan adanya kebijakan hukum perlindungan, dan pengelolaan lingkungan hidup maka pemanfaatan sumber daya alam tidak menjadi pengurasan sumber daya alam. ${ }^{6}$ Pencemaran lingkungan hidup dapat dikendalikan dengan baik. Berdasarkan uraian latar belakang yang telah disampaikan, maka rumusan masalah dalam penulisan ini adalah; 1) Bagaimanakah politik hukum lingkungan di Indonesia dalam hal perlindungan, pengelolaan dan pengendalian pencemaran lingkungan hidup di Indonesia? 2) Bagimanakah pelaksanaan pengendalian pencemaran lingkungan hidup dan penegakan hukumnya di Indonesia?

\section{B. Pembahasan}

1. Politik Hukum Lingkungan Hidup: Perlindungan, Pengelolaan dan Pengendalian Pencemaran Lingkungan Hidup Menurut UUPLH 2009

diterapkan keberlanjutan lingkungan atau yang disebut Good Enviromental Governance. Dengan dilaksanakannya tata kelola pemerintahan yang baik akan memastikan pelaksanaan pembangunan yang berorientasi lingkungan telah benar-benar terlaksana. Adanya Good Enviromental Governance dapat memastikan bahwa pelaksanan pembangunan yang berorientasi perlindungan dan pemeliharaan lingkungan akan dilaksanakan. Lihat di Adi Prasetio, Good Governance dan Pembangunan Berkelanjutan; Meretas Pemikiran Naya: 37 Tahun Masa Pengabdian Prof. Suma Tjahja Djajadiningrat, Ph.D. ICSD \& SDM ITB, (Bandung: 2009).

${ }^{5}$ Askin Mohammad, Hukum Lingkungan, (Jakarta: Penerbit Yayasan Peduli Energi Indonesia (YPEI), 2008), hlm. 45.

${ }^{6}$ Takdir Rahmadi, Hukum Lingkungan di Indonesia, (Jakarta: Raja Grafindo, 2014), hlm. 2 
Menurut David Kairsy, politik hukum merupakan kebijaksanaan negara untuk menerapkan hukum. ${ }^{7}$ Teuku Muhammad Radhie mengonsepsi politik hukum sebagai pernyataan kehendak penguasa negara mengenai hukum yang berlaku di wilayah suatu Negara dan mengenai arah ke mana hukum hendak dikembangkan. ${ }^{8}$ E. Utrecht memaparkan bahwa politik hukum adalah suatu ilmu normatif yaitu ilmu yang menentukan hal-hal yang seharusnya ada. ${ }^{9}$ Sesuatu yang seharusnya ada dalam bentuk normatif adalah peraturan perundang-undangan, baik yang bersifat materiil maupun formil. Politik hukum kemudian berperan untuk menentukan cara dan tujuan yang hendak dicapai dalam pembuatan ataupun pelaksanaan suatu produk hukum. Sejalan dengan hal tersebut Satijpto Rahardjo berpendapat, dalam politik hukum, maka pembangunan hukum harus memiliki makna ganda. Pertama, sebagai suatu usaha untuk memperbaharui hukum positif sendiri, sehingga sesuai dengan kebutuhan untuk melayani masyarakat pada tingkat perkembangannya yang mutakhir. Kedua, sebagai usaha untuk memfungsionalkan hukum dalam masa pembangunan, yaitu dengan cara turut mengadakan perubahan-perubahan sosial sebagaimana dibutuhkan oleh masyarakat yang sedang membangun. ${ }^{10}$

Moh. Mahfud MD menyatakan bahwa politik hukum adalah legal policy yang akan atau telah dilaksanakan secara nasional oleh Pemerintah Indonesia. Legal policy ini terdiri dari, pertama, pembangunan hukum yang berintikan pembuatan dan pembaruan terhadap materi-materi hukum agar dapat sesuai dengan kebutuhan. Kedua, pelaksanaan ketentuan hukum yang telah ada termasuk penegasan fungsi lembaga dan pembinaan para penegak hukum. ${ }^{11}$ Berdasarkan pengertian tersebut menurut Moh. Mahfud terlihat politik hukum mencakup proses pembuatan dan pelaksanaan hukum yang dapat menunjukkan sifat dan ke arah mana hukum dibangun dan ditegakkan. ${ }^{12}$ Berdasarkan pengertian tentang konsepsi politik hukum di atas, dalam kajian ini politik hukum dimaksudkan sebagai kebijakan hukum yang menjadi dasar dari pengelolaan lingkungan hidup di Indonesia. Berbicara mengenai kebijakan hukum tentu UUD 1945 sebagai basic norm menjadi rujukan pertama, termasuk dalam pengelolaan lingkungan hidup dan sumber daya alam.

\footnotetext{
${ }^{7}$ David Kairsy, The Politics of Law, A Progressive Critique, (New York: Pantheon Books, 1990), hlm. xi.

${ }^{8}$ Teuku Muhammad Radhie dalam majalah PRISMA, no. 6 tahun keI-II, Desember 1973

${ }^{9}$ Otong Rosadi dan Andi Desmon, Studi Politik Hukum: Suatu Optik Politik Hukum, Edisi II, (Yogyakarta: PT. Thafa Media, 2013), hlm. 6.

${ }^{10}$ Satjipto Rahardjo, Hukum dan Perubahan Sosial, (Yogyakarta: Genta Publishing, 2009), hlm. 203.

${ }^{11}$ Mahfud MD, Politik Hukum di Indonesia, (Jakarta: LP3ES, 1998), hlm. 9.

${ }^{12}$ Ibid.
} 
Sebelum adanya perubahan kedua dan keempat UUD 1945, satusatunya ketentuan konstitusi yang menjadi landasan hukum bagi pengelolaan lingkungan dan sumber daya alam adalah Pasal 33 ayat (3), yang lebih banyak ditafsirkan sebagai pemanfaatan dan ekploitasi sumber daya alam dengan justifikasi untuk mencapai kesejahteraan rakyat, sehingga aspek perlindungan dan keberlanjutan lingkungan dan sumber daya alam menjadi terabaikan.

Perubahan kedua dan keempat UUD 1945, telah memasukkan ketentuan baru terkait dengan pengelolaan lingkungan hidup dan pemanfaatan sumber daya alam, yaitu Pasal $28 \mathrm{H}$ ayat (1) dan Pasal 33 ayat (4) dan (5) UUD 1945. Pasal 28H ayat (1) menyatakan bahwa "setiap orang berhak hidup sejahtera lahir dan batin, bertempat tinggal, dan mendapatkan lingkungan hidup baik dan sehat serta berhak memperoleh pelayanan kesehatan." Pasal 33 ayat 4 UUD 1945 "Perekonomian nasional diselenggarakan berdasar atas demokrasi ekonomi dengan prinsip kebersamaan, efisiensi berkeadilan, berkelanjutan, berwawasan lingkungan, kemandirian, serta dengan menjaga keseimbangan kemajuan dan kesatuan ekonomi nasional." Sementara Pasal 33 ayat (5) menegaskan bahwa ketentuan lebih lanjut diatur dengan undang-undang.

Dari ketentuan Pasal $28 \mathrm{H}$ ayat (1), Pasal 33 ayat (3), (4) dan (5) UUD 1945 , terdapat 5 hal penting yang menjadi kebijakan hukum negara dalam pengelolaan lingkungan hidup dan pemanfaatan sumber daya alam.

a. pengelolaan lingkungan dan pemanfaatan sumber daya alam harus diletakkan dalam kerangka pengakuan, perlindungan dan pemenuhan hak asasi setiap warga negara atas lingkungan hidup yang baik dan sehat. Dengan kata lain hak asasi atas lingkungan hidup yang baik dan sehat tidak dapat dikorbankan akibat pelaksanaan pembangunan dan pemanfaatan sumber daya alam;

b. pengelolaan lingkungan hidup dan pemanfaatan sumber daya alam merupakan tanggung jawab negara, di mana melalui hak menguasai negara, negara membuat aturan-aturan dan kebijakan pemanfaatan lingkungan dan sumber daya alam;

c. kesejahteraan rakyat menjadi dasar filosofis dan sosiologis bagi segala aktivitas dan kegiatan pengelolaan lingkungan hidup dan pemanfaatan sumber daya alam dipergunakan bagi kesejahteraan rakyat;

d. pengelolaan lingkungan hidup dan pemanfaatan sumber daya alam merupakan sarana untuk mencapai pembangunan berkelanjutan berwawasan lingkungan hidup, dalam arti sasaran pengelolaan lingkungan hidup dan pemanfaatan sumber daya alam tidak saja mencakup kesejahteraan rakyat, melainkan juga aspek keberlanjutan lingkungan hidup dan kemajuan ekonomi nasional; dan 
e. adanya pendelegasian pengaturan lebih lanjut mengenai pengelolaan lingkungan hidup dengan undang-undang.

UUD 1945 menyatakan bahwa lingkungan hidup yang baik dan sehat merupakan hak asasi dan hak konstitusional bagi setiap warga negara Indonesia. Oleh karena itu, negara, pemerintah, dan seluruh pemangku kepentingan berkewajiban untuk melakukan perlindungan dan pengelolaan lingkungan hidup dalam pelaksanaan pembangunan berkelanjutan agar lingkungan hidup Indonesia dapat tetap menjadi sumber dan penunjang hidup bagi rakyat Indonesia serta makhluk hidup lain. ${ }^{13}$

Berdasarkan hal tersebut maka lahirnya Undang-Undang Nomor 32 Tahun 2009 tentang Perlindungan dan Pengelolaan Lingkungan Hidup merupakan sumber hukum formal tingkat undang-undang dalam konteks lingkungan hidup di Indonesia. ${ }^{14}$ Secara filosofis Undang-Undang Nomor 32 Tahun 2009 Tentang Perlindungan dan Pengelolaan dan Perlindungan Hidup, ini memandang dan menghargai bahwa arti penting akan hak-hak asasi berupa hak atas lingkungan hidup yang baik dan sehat bagi warga negara. ${ }^{15}$

Undang-Undang No. 32 Tahun 2009 tentang Perlindungan dan Pengelolaan Lingkungan Hidup (UUPLH) sebagai pengganti UU No. 23 Tahun 1997 membawa perubahan mendasar dalam pengaturan pengelolaan lingkungan hidup di Indonesia. Karena dilihat dari judul UUPLH 2009 adanya penekanan pada upaya perlindungan lindungan hidup yang diikuti dengan kata pengelolaan lingkungan hidup. Padahal dari segi kaidah bahasa, dalam kata pengelolaan telah termasuk didalamnya kegiatan atau aktivitas perlindungan. Dengan adanya penekanan pada upaya perlindungan, di samping kata pengelolaan lingkungan hidup, UU 32 Tahun 2009 memberikan perhatian serius pada kaidah-kaidah pengaturan yang bertujuan memberikan jaminan bagi terwujudnya pembangunan berkelanjutan dan memastikan lingkungan hidup dapat terlindungi dari usaha atau kegiatan yang menimbulkan kerusakan atau pencemaran lingkungan hidup.

Dikaitkan dengan pendapat Teuku Muhammad Radhie mengenai politik hukum sebagai arah (tujuan) ke mana hukum hendak dikembangkan, maka UUPLH menetapkan arah (tujuan) kemana hukum perlindungan dan pengelolaan lingkungan hidup hendak dikembangkan. Menurut Pasal 3 UU 32 tahun 2009, perlindungan dan pengelolaan lingkungan hidup bertujuan:

a. melindungi wilayah Negara Kesatuan Republik Indonesia dari pencemaran dan/atau kerusakan lingkungan hidup;

\footnotetext{
${ }^{13}$ Penjelasan Umum 1, Undang-Undang Nomor 32 Tahun 2009 Tentang Perlindungan dan Pengelolaan Lingkungan Hidup.

${ }^{14}$ Op.Cit., Takdir Rahmadi, hlm. 50.

${ }^{15}$ Dalam Siti Kotijah, 2011, Evaluasi Undang-Undang Nomor 32 Tahun 2009, 2009, Jurnal Hukum No 2 Volume 18, hlm. 390.
} 
b. menjamin keselamatan, kesehatan, dan kehidupan manusia;

c. menjamin kelangsungan kehidupan makhluk hidup dan kelestarian ekosistem;

d. menjaga kelestarian fungsi lingkungan hidup;

e. mencapai keserasian, keselarasan, dan keseimbangan lingkungan hidup;

f. menjamin terpenuhinya keadilan generasi masa kini dan generasi masa depan;

g. menjamin pemenuhan dan perlindungan hak atas lingkungan hidup sebagai bagian dari hak asasi manusia;

h. mengendalikan pemanfaatan sumber daya alam secara bijaksana;

i. mewujudkan pembangunan berkelanjutan; dan

j. mengantisipasi isu lingkungan global.

Untuk mencapai tujuan di atas, UUPLH menetapkan sejumlah instrumen hukum pencegahan pencemaran dan/atau kerusakan lingkungan hidup yaitu Kajian Lingkungan Hidup Strategis (KLHS), Tata Ruang, Baku Mutu Lingkungan Hidup, Kriteria Baku Kerusakan Lingkungan Hidup, AMDAL, Upaya Pengelolaan Lingkungan Hidup dan Upaya Pemantauan Lingkungan Hidup (UKL-UPL), Perizinan, Instrumen Ekonomis Lingkungan, Peraturan Perundang-undangan Berbasiskan Lingkungan Hidup, Anggaran Berbasiskan Lingkungan Hidup, Analisis Risiko Lingkungan Hidup, Audit Lingkungan Hidup, dan instrumen lain sesuai kebutuhan dan perkembangan ilmu pengetahuan, di mana KLHS menempati posisi puncak dalam pencegahan dan pencemaran lingkungan hidup. Penekanan pada aspek perlindungan lingkungan hidup, juga terlihat dari adanya dua tahapan izin yang harus dipenuhi oleh setiap orang atau pelaku usaha/kegiatan yang terkait dengan pengelolaan lingkungan hidup yaitu adanya kewajiban memperoleh izin lingkungan terlebih dahulu sebagai syarat untuk mendapat izin usaha dan/atau kegiatan. Di samping instrumen pencegahan, juga diatur instrumen penegakan hukum (administrasi, perdata, dan pidana) beserta penerapan sanksi administrasi, ganti rugi dan sanksi pidana.

Penetapan UUPLH berusaha memastikan adanya perlindungan dan pengelolaan lingkungan hidup secara berkelanjutan dan berwawasan lingkungan hidup sedini mungkin yaitu melalui dari tingkat kebijakan, rencana dan program pembangunan (KLHS), maupun pada kajian lingkungan hidup bagi kegiatan atau usaha seperti telah dikenal selama ini, melalui mekanisme AMDAL.

Selain itu, untuk mewujudkan tujuan yang telah dikemukakan di atas, UPLH, yang pertama isinya yang disingkat menjadi 6P, yaitu perencanaan, pemanfaatan, pengendalian, pemeliharaan, pengawasan, dan penegakan 
hukum, ${ }^{16}$ untuk melestarikan fungsi lingkungan hidup dan mencegah terjadinya pencemaran dan/atau kerusakan lingkungan hidup.

Sebagai dasar pijakan dari perlindungan dan pengelolaan lingkungan hidup ialah perencanaan. ${ }^{17}$ Dengan perencanaan yang baik dan benar, perlindungan dan pengelolaan lingkungan hidup akan dapat berjalan dengan baik pula. Begitu juga dengan pemanfaatan, pengendalian, pengawasan dan penegakan hukum bisa baik dan benar kalau perencanaannya juga baik sebelumnya.

Selain perencanaan yang baik dan benar dalam perlindungan dan pengelolaan lingkungan hidup, kita juga bisa menjumpai di dalam undangundang perlindungan dan pengelolaan lingkungan hidup yaitu daya dukung dan daya tampung lingkungan hidup dalam pemanfaatan sumber daya alam. ${ }^{18}$ Agar pemanfaatan sumber daya alam itu tidak rusak keberlanjutan proses, fungsi, produktivitas lingkungan hidup dan keselamatan mutu hidup dan kesejahteraan masyarakat, harus didasarkan oleh daya dukung dan daya tampung lingkungan hidup tersebut untuk tetap menjaga pelestarian fungsi lingkungan hidup.

Dari keenam aspek penting perlindungan dan pengelolaan lingkungan hidup sebagaimana diatur dalam Pasal 4 UUPLH, ada empat (4) aspek yang memunyai posisi sangat strategis, yaitu (a) perencanaan sebagai dasar dari semua perlindungan dan pengelolaan lingkungan hidup; (b) pengendalian yang berisikan berbagai instrumen penting yang menentukan keberhasilan kita dalam mencapai sasaran utama perlindungan dan pengelolaan lingkungan hidup, yaitu menjaga daya dukung dan daya tampung lingkungan hidup; (c) pengawasan sebagai aspek atau faktor penting yang menentukan berhasil tidaknya pelaksanaan perlindungan dan pengelolaan lingkungan hidup; dan (d) penegakan hukum sebagai aspek atau faktor paling penting yang menjamin keberhasilan pelaksanaan perlindungan dan pengelolaan lingkungan hidup. ${ }^{19}$

Selain empat (4) aspek di atas tadi yang menjamin terjaganya daya dukung dan daya tampung lingkungan hidup, masih ada lagi instrumen penting lainnya yang mendukung pengelolaan dan perlindungan lingkungan hidup, yaitu pertama pengendalian dampak lingkungan hidup yang meliputi: kajian lingkungan hidup strategis, tata ruang, baku mutu lingkungan hidup, kriteria baku kerusakan lingkungan hidup, analisis mengenai dampak

\footnotetext{
${ }^{16}$ Pasal 4 Undang-Undang Nomor 32 Tahun 2009 Tentang Perlindungan dan Pengelolaan Lingkungan Hidup.

${ }^{17}$ Lihat Bab III Undang-Undang Nomor 32 Tahun 2009 Tentang Perlindungan dan Pengelolaan Lingkungan Hidup.

18 Lihat Bab IV Undang-Undang Nomor 32 Tahun 2009 Tentang Perlindungan dan Pengelolaan Lingkungan Hidup.

${ }^{19}$ Op.Cit., A. Sonny Keraf, hlm. 254.
} 
lingkungan hidup, UKL-UPL, izin lingkungan hidup, instrumen ekonomi lingkungan hidup, peraturan perundang-undangan yang berbasis lingkungan hidup, anggaran yang berbasis lingkungan hidup, analisis risiko lingkungan hidup, audit lingkungan hidup, kedua pengawasan dan penegakan hukum lingkungan.

\section{Pelaksanaan Pengendalian Pencemaran Lingkungan Hidup dan Penegakan Hukumnya}

a. Wewenang untuk Melakukan Pengawasan

Berdasarkan Bab XII Undang-Undang Nomor 32 Tahun 2009 bagian kesatu mengatur tentang pengawasan dalam perlindungan dan pengelolaan lingkungan hidup mulai Pasal 71 sampai Pasal 75. Pasal 71 ayat (1) menteri, gubernur, atau bupati/walikota sesuai dengan kewenangannya wajib melakukan pengawasan terhadap ketaatan penanggung jawab usaha dan/atau kegiatan atas ketentuan yang ditetapkan dalam peraturan perundangundangan di bidang perlindungan dan pengelolaan lingkungan hidup.

Ayat (2) menteri, gubernur, atau bupati/walikota dapat mendelegasikan kewenangannya dalam melakukan pengawasan kepada pejabat/instansi teknis yang bertanggung jawab di bidang perlindungan dan pengelolaan lingkungan hidup. Ayat (3) dalam melaksanakan pengawasan, menteri, gubernur, bupati/walikota menetapkan pejabat pengawas lingkungan hidup yang merupakan pejabat fungsional.

Instansi yang berwenang dalam melakukan pelaksanaan pengendalian lingkungan hidup, termasuk dampak lingkungan hidup adalah kantor lingkungan hidup/Bapedal di tingkat Provinsi dan kantor lingkungan hidup/Bapedalda di tingkat Kabupaten/Kotamadya. Kantor lingkungan hidup/Bapedal maupun Bapedalda termasuk lembaga teknis daerah yang dipimpin oleh seorang kepala dan bertanggung jawab langsung kepada gubernur atau bupati/walikota. Pembiayaan kegiatan operasionalnya adalah dimasukkan ke dalam APBD Provinsi atau Kabupaten/Kota masing masing, karena kedua instansi ini termasuk perangkat kerja daerah.

\section{b. Kewenangan Gubernur dalam Pengendalian Pencemaran Air Akibat Limbah Industri}

Pada dasarnya kewenangan pengendalian pencemaran air di daerah baik yang berasal dari limbah industri maupun dari sumber lain, berada pada gubernur sebagai kepala daerah tingkat I. Hal ini diatur baik dalam pasal 13 Peraturan Pemerintah Nomor 20 Tahun 1990 tentang pengendalian pencemaran air maupun di dalam Pasal 18 ayat (2) Peraturan Pemerintah Nomor 41 Tahun 1999 tentang Pengendalian Pencemaran Udara. Akan tetapi dalam pengendalian pencemaran udara, kewenangan gubernur adalah 
melakukan koordinasi, terutama dalam hal pencemaran lintas Kabupaten/Kota. Pencemaran yang terjadi pada suatu daerah kabupaten/kota yang berwenang melaksanakan pengendaliannya dalah Bupati/ Walikota daerah yang bersangkutan.

Tindakan-tindakan yang dilakukan Gubernur adalah: 1) menunjuk instansi teknis yang bertanggung jawab di bidang pengelolaan lingkungan hidup di daerah. ${ }^{20}$ Untuk melakukan inventarisasi kualitas dan kuantitas air, data ini digunakan untuk menentukan peruntukan air dan baku mutu air, dasar perhitungan daya tampung beban pencemaran air dan dasar penilaian tingkat pencemaran air; 2) mengidentifikasikan sumber-sumber pencemaran air $^{21}$; 3) menetapkan baku mutu limbah cair yang lebih ketat dari yang ditentukan oleh menteri lingkungan hidup setelah berkonsultasi dengan menteri lingkungan hidup; 4) memberikan izin pembuangan limbah cair ke dalam air (seperi sungai, danau) yang biasanya dicantumkan dalam izin HO (Pasal 25 jo, 26 ayat (1 dan 2) PP 20 Tahun 1990). Apabila pelaku kegiatan ingin membuang limbah cair ke tanah permohonan izin harus dimintakan kepada menteri lingkungan hidup; 5) melakukan pengawasan kualitas air dengan menunjuk instansi di daerah yang meliputi tugas pemantauan dan evaluasi baku mutu limbah cair, pemantauan dan perubahan kualitas air, pengumpulan dan evaluasi data yang berhubungan dengan pencemaran air serta evaluasi laporan dari penanggung jawab kegiatan tentang pembuangan limbah cair dan analisisnya. ${ }^{22}$

\section{c. Kewenangan Gubernur dalam Pengendalian Pencemaran Udara}

Adapun kewenangan Gubernur dalam hal pengendalian pendemaran udara meliputi: 1) dapat menentukan baku mutu udara ambien daerah berdasarkan baku mutu ambien nasional, bahkan Gubernur dapat menentukan baku mutu yang lebih ketat; ${ }^{23}$ 2) berdasarkan keputusan Menteri Negara Lingkungan Hidup No KEP. -13/MENLH/ 3/1995, Gubernur diberi kewenangan untuk menetapkan baku mutu emisi yang lebih ketat dari ketentuan yang ditetapkan oleh Menteri Negara Lingkungan Hidup, namun penetapan ini harus mengikutsertakan pihak-pihak yang berkepentingan (dalam hal ini bisa berarti stakeholders, pelaku usaha maupun masyarakat); 3) Gubernur dapat menentukan baku tingkat kebisingan yang lebih ketat dari yang diatur oleh menteri negara lingkungan hidup. Dalam keputusan menteri lingkungan hidup, tingkat kebisingan bagi insdustri yang diperbolehkan adalah $70 \mathrm{~dB}$; 4) Gubernur/Bupati/Walikota berwenang untuk melakukan

\footnotetext{
${ }^{20}$ Lihat Pasal 4 ayat (1) PP Nomor 20 Tahun 1990.

${ }^{21}$ Lihat Pasal 5 ayat (1) PP Nomo 20 Tahun 1990.

${ }^{22}$ Lihat Pasal 30 PP Nomor 20 Tahun 1990.

${ }^{23}$ Lihat Pasal 5 ayat (2) PP No. 41 Tahun 1999.
} 
pengawasan terhadap pelaku kegiatan usaha/kegiatan industri yang dibantu oleh BPLHD.

\section{d. Penegakan Hukum Lingkungan}

Hukum lingkungan adalah sebuah bidang hukum yang memiliki kekhasan yang oleh Drupsteen disebut sebagai bidang hukum fungsional (functioneel rechtsgebeid), yaitu didalamnya terdapat unsur-unsur hukum administrasi, hukum pidana dan hukum perdata. ${ }^{24}$ Oleh sebab itu, penegakan hukum lingkungan dapat dimaknai sebagai penggunaan atau penerapan instrumen-instrumen dan sanksi-sanksi dalam lapangan hukum administrasi, hukum pidana, dan hukum perdata dengan tujuan memaksa subjek hukum yang menjadi sasaran mematuhi peraturan perundang-undangan lingkungan hidup.

Penggunaan instrumen dan sanksi hukum administrasi dilakukan oleh instansi pemerintah dan juga oleh warga atau badan hukum perdata. Gugatan Tata Usaha Negara merupakan sarana hukum administrasi negara yang dapat digunakan warga atau badan hukum perdata terhadap instansi atau pejabat pemerintah yang menerbitkan keputusan tata usaha negara yang secara formal atau materiil bertentangan dengan peraturan perundang-undangan lingkungan hidup. Penggunaan sanksi-sanksi hukum pidana hanya dapat dilakukan oleh instansi-instansi pemerintah. Penggunaan instrumen hukum perdata, yaitu gugatan perdata dapat dilakukan oleh warga, badan hukum perdata dan juga instansi pemerintah. Namun, jika dibandingkan di antara bidang hukum, sebagian besar norma-norma hukum lingkungan termasuk ke dalam wilayah hukum administrasi. ${ }^{25}$

Dalam Kabinet Indonesia Bersatu jilid II yang dinahkodai oleh Susilo Bambang Yudhoyono dan Budiono ini upaya untuk melakukan penegakan hukum lingkungan dan penanganan berbagai kasus lingkungan belum menunjukkan hasil menggembirakan. Pemerintah oleh kalangan aktivis lingkungan dinilai hanya mengurusi masalah politik dan sibuk mengurusi partai tanpa ada keberpihakan pada lingkungan. Akibatnya persoalan lingkungan, seperti kasus pencemaran Buyat, illegal loging, kebakaran hutan pencemaran dan perusakan lingkungan di sejumlah daerah tidak dapat ditangani secara tuntas. Kebijakan pemerintah yang tidak memihak pada lingkungan berakibat pada terjadinya musibah yang terus terjadi secara beruntun di berbagai tempat hampir di seluruh wilayah Indonesia. Gambaran tersebut menunjukkan adanya indikasi bahwa bekerjanya lembaga

\footnotetext{
${ }^{24}$ Takdir Rahmadi, Op. Cit., hlm. 207 atau lihat juga pada Siti Sundari Rangkuti, Hukum Lingkungan dan Kebijakan Nasional, (Surabaya: Airlangga University Press, 1996), hlm. 30

${ }^{25}$ Ibid., hlm. 208.
} 
pengadilan dan penegakan hukum lingkungan di Indonesia masih amat dipengaruhi kepentingan politik. ${ }^{26}$ Seperti contoh pada tahun 1995 Wahana Lingkungan Hidup Indonesia (WALHI) melakukan gugatan melawan Departemen Petambangan dan Energi yang menerbitkan amdal kepada PT. Freeport ditolak oleh Pengadilan Tata Usaha Negara Jakarta.

Undang-undang Nomor 32 Tahun 2009 tentang Perlindungan dan Pengelolaan Lingkungan Hidup (UUPPLH) mengatur permasalahan lingkungan sebagai dasar pedoman bagi aparat penegak hukum untuk menjerat pelaku tindak pidana lingkungan dikenakan hukuman pidana sesuai aturan yang berlaku. Pasal 1 angka 16, menyatakan definisi perusakan lingkungan hidup adalah "Tindakan orang yang menimbulkan perubahan langsung atau tidak langsung terhadap sifat fisik, kimia, dan atau hayati lingkungan hidup sehingga melampaui ktriteria baku kerusakan lingkungan hidup". Rumusan Pasal ini mencantumkan kalimat "tindakan orang" yang tidak ada di dalam UUPLH sebelumnya, sehingga memberikan keleluasan aparat untuk segera menindak bagi pelaku perusakan lingkungan baik itu perseorangan maupun kelompok (perusahaan).

Pasal 1 angka 17 juga menyatakan bahwa kerusakan lingkungan hidup adalah perubahan langsung dan/atau tidak langsung terhadap sifat fisik, kimia, dan/atau hayati lingkungan hidup yang melampaui kriteria baku kerusakan lingkungan hidup. Dengan demikian di dalam undang-undang ini, perbuatan yang menimbulkan pencemaran lingkungan dan atau perusakan lingkungan hidup yang dilakukan dengan sengaja atau tidak sengaja atau kealpaan diarahkan menjadi perbuatan tindak pidana yang dalam undangundang ini merupakan kejahatan. ${ }^{27}$

Sesuai Pasal 71 ayat (1) Menteri, gubernur, atau bupati/walikota sesuai dengan kewenangannya wajib melakukan pengawasan terhadap ketaatan penanggung jawab usaha dan/atau kegiatan atas ketentuan yang ditetapkan dalam peraturan perundang undangan di bidang perlindungan dan pengelolaan lingkungan hidup; ayat (2) menteri, gubernur, atau bupati/walikota dapat mendelegasikan kewenangannya dalam melakukan pengawasan kepada pejabat/instansi teknis yang bertanggung jawab di bidang perlindungan dan pengelolaan lingkungan hidup; ayat (3) dalam melaksanakan pengawasan, menteri, gubernur, bupati/walikota menetapkan pejabat pengawas lingkungan hidup yang merupakan pejabat fungsional.

Di dalam Pasal 76 UUPPLH ini mengatur tentang sanksi administrasi. menteri, gubernur, atau bupati/walikota menerapkan sanksi administratif kepada penanggung jawab usaha dan/atau kegiatan jika dalam pengawasan ditemukan pelanggaran terhadap izin lingkungan. Sanksi administratif terdiri

\footnotetext{
${ }^{26}$ Absori, Penegakan Hukum Lingkungan Pada Era Reformasi, artikel dalam Jurnal Ilmu Hukum, Vol. 8. No. 2, 2005, hlm. 10.

${ }^{27}$ Lihat Pasal 97 UUPPLH.
} 
atas; teguran tertulis, paksaan pemerintah, pembekuan izin lingkungan atau pencabutan izin lingkungan.

Pasal 80 ayat (1) mengatur tentang paksaan pemerintah kepada penanggung jawab usaha dan/atau kegiatan yang yang melanggar izin lingkungan berupa; a) penghentian sementara kegiatan produksi; b) pemindahan sarana produksi; c) penutupan saluran pembuangan air limbah atau emisi; d) pembongkaran; e) penyitaan terhadap barang atau alat yang berpotensi menimbulkan pelanggaran; f) penghentian sementara seluruh kegiatan; g) tindakan lain yang bertujuan untuk menghentikan pelanggaran dan tindakan pemulihan fungsi lingkungan hidup.

Pengenaan paksaan pemerintah dapat dijatuhkan tanpa didahului teguran apabila pelanggaran yang dilakukan menimbulkan; a) ancaman yang sangat serius bagi manusia dan lingkungan hidup; b) dampak yang lebih besar dan lebih luas jika tidak segera dihentikan pencemaran dan/atau perusakannya; c) kerugian yang lebih besar bagi lingkungan hidup jika tidak segera dihentikan pencemaran atau kerusakannya ayat (2).

Pasal 87 mengatur tentang kewajiban penanggung jawab usaha untuk memberi ganti rugi kepada orang atau lingkungan yang dirugikan. Selain korban maka organisasi lingkungan hidup juga dapat meminta pertanggungjawaban perdata kepada pelaku kegiatan usaha. ${ }^{28}$ Akan tetapi apabila gugatan tersebut dilakukan oleh organisasi lingkungan hidup, permintaan yang dapat diajukan hanya sebatas melakukan tindakan tertentu, kecuali biaya atau pengeluaran nyata. Sehingga bagi masyarakat yang menderita kerugian akibat pencemaran dan atau perusakan lingkungan hidup dapat melakukan-gugatan secara bersama-sama dengan cara gugatan perwakilan kelompok. ${ }^{29}$ Hal terpenting dalam melakukan gugatan ini, kelompok masyarakat dapat menempuh cara-cara di luar pengadilan yang dikenal dengan mekanisme alternatif penyelesaian sengketa.

Bab XIV mengatur tentang Penyidikan dan Pembuktian. Selain penyidik pejabat polisi, pejabat pegawai negeri sipil tertentu di lingkungan instansi pemerintah yang lingkup tugas dan tanggung jawabnya di bidang perlindungan dan pengelolaan lingkungan lingkungan hidup diberi wewenang sebagai penyidik sebagai dimaksud dalam hukum acara pidana untuk melakukan penyidikan tindak pidana lingkungan hidup. Penyidik pegawai negeri sipil berwenang antara lain : 1) melakukan pemeriksaan atas kebenaran laporan atau keterangan berkenaan dengan tindak pidana di bidang perlindungan dan pengelolaan lingkungan hidup; 2) melakukan pemeriksaan terhadap setiap orang yang diduga melakukan tindak pidana di bidang perlindungan dan pengelolaan lingkungan hidup; 3) meminta

\footnotetext{
${ }^{28}$ Lihat Pasal 92

${ }^{29}$ Lihat Pasal 91
} 
keterangan dan bahan bukti dari setiap orang berkenaan dengan peristiwa tindak pidana di bidang lingkungan hidup; 4) melakukan pemeriksaan atas pembukuan, catatan, dan dokumen lain berkenaan dengan tindak pidana di bidang lingkungan hidup; 5) melakukan penyitaan terhadap bahan dan barang hasil pelanggaran yang dapat dijadikan bukti dalam perkara tindak pidana lingkungan hidup; 6) meminta bantuan ahli dalam rangka tugas penyidikan; 7) menghentikan penyidikan; dan 8) melakukan penggeledahan terhadap badan, pakaian, ruangan atau tempat lain yang diduga merupakan tempat dilakukannya tindak pidana atau menangkap dan menahan pelaku tindak pidana.

Adapun untuk pembuktian diatur dalam Pasal 96, alat bukti yang sah dalam tuntutan tindak pidana lingkungan terdiri atas; keterangan saksi, keterangan ahli, surat, petunjuk, keterangan terdakwa, alat bukti lain, termasuk alat bukti yang diatur dalam peraturan perundang-undangan. Sistem pembuktian yang harus dilakukan penggugat atau aparat penegak hukum merupakan problem pembuktian yang sulit dan pelik selama ini. Karena aparat penegak hukum akan mengalami kesulitan terutama dalam masalah pembuktiannya yang berkaitan dengan hal-hal yang bersifat sangat teknis untuk menentukan klasifikasi ataupun unsur-unsur yang harus dipenuhi sehingga dikatakan sebagai pelaku tindak pidana lingkungan. Kemudian juga adanya keterbatasan pengetahuan tentang permasalahan, sarana, prasarana, dana maupun pemahaman terhadap substansi hukum karena rata-rata korban adalah orang-orang yang berpendidikan rendah dan kondisi ekonominya lemah. Setelah melihat uraian tentang pembaharuan dan perbedaan substansial terhadap Undang-Undang Nomor 32 Tahun 2009, apakah undang-undang tersebut berlaku efektif dalam menanggulangi permasalahan lingkungan terutama masih sering terjadinya pencemaran air oleh limbah industri atau ada segelintir manusia yang secara sadar masih membuang sampah ke dalam sungai, sehingga sungai tersebut menjadi kotor. $^{30}$

Efektivitas hukum dapat dijelaskan sebagai suatu keadaan di mana terjadi kesesuaian antara cita-cita yang terkandung di dalam substansi hukum dengan realitas berlakunya hukum tersebut di dalam masyarakat. Hukum dianggap kurang atau tidak efektif apabila terdapat disparitas antara realita hukum dan ideal hukum, sehingga hukum tersebut harus dirombak dan disusun kembali. Kalau ideal hukum itu mengacu kepada tujuan atau citacita yang terkandung di dalam isi/substansi hukum, realita hukum mengacu kepada pengertian penerapan hukum yang indikatornya adalah kesadaran dan/atau kepatuhan hukum yang tercermin dalam perilaku warga masyarakat

\footnotetext{
${ }^{30}$ Sutrisno, Politik Perlindungan dan Pengelolaan Lingkungan Hidup, Jurnal Hukum No. 3 Volume 18, 2011, hlm. 461.
} 
tersebut. Maka dapat dikatakan bahwa efektivitas hukum yang berlaku dalam suatu masyarakat tidak terlepas dari konsep kesadaran hukum dan atau kepatuhan hukum dari masyarakat itu sendiri. ${ }^{31}$

Agar dapat berlaku efektif, maka hukum dalam kegiatannya ditegakkan dengan dukungan sanksi baik administrasi, sanksi perdata, maupun sanksi pidana. Sehingga untuk menjamin dukungan sanksi tersebut, maka haruslah dijalin hubungan harmonisasi dan sinkronisasi pada semua lintas kehidupan bersama, dengan menjadikan satu panduan sebagai pedoman berkaitan mengenai bagaimana seharusnya bertindak dan diharapkan bertindak. Salah satu cara efektivitas dalam penegakan hukum lingkungan adalah dengan menggunakan pendekatan multi door system, yaitu penggunaan berbagai macam peraturan perundang-undangan untuk menangani kasus terkait lingkungan hidup, karena dengan penegakan hukum yang konsisten akan mengaktifkan juga instrumen pencegahan.

Masih sering terjadinya pencemaran yang dilakukan oleh pihak perusahaan atau industri dan masih rendahnya ketaatan dan kepatuhan serta kesadaran warga masyarakat untuk menjaga lingkungan yang bersih dan sehat menjadi indikator bahwa penegakan hukum terhadap pengelolaan lingkungan yang bersih dan sehat belum berjalan. Dengan demikian secara implementasi efektivitas UUPLH masih rendah hal ini dikarenakan penegakan hukum terutama dalam masalah pembuktian sulit dilakukan dan pengawasan dalam rangka pengendalian dan pengelolaan lingkungan hidup dapat dikatakan masih jalan di tempat walaupun dari aspek politik hukum secara substansial isi/materi hukum lingkungan tersebut telah banyak terjadi perubahan disesuaikan dengan kondisi sosial masyarakat. ${ }^{32}$

\section{Penutup}

Politik hukum lingkungan berdasarkan Undang-Undang Nomor 32 tahun 2009 tentang Perlindungan dan Pengelolaan Lingkungan Hidup belum berjalan sesuai dengan tujuan politik hukumnya, karena sumber daya alam yang ada belum dapat dipergunakan untuk sebesar-besarnya kemakmuran dan kesejahteraan rakyat. Selain itu juga masih banyak terjadi pencemaran air, polusi udara, pembalakan hutan dan perbuatan lain para pihak-pihak yang merusak lingkungan. Pelaksanakan pengelolaan lingkungan hidup untuk melestarikan dan mengembangkan kemampuan lingkungan hidup yang serasi, selaras dan seimbang guna menunjang terlaksananya pembangunan yang berkelanjutan yang berwawasan lingkungan hidup. Penegak hukum dalam memahami sistem hukum lingkungan dirasakan masih mengalami kesulitan. Kurangnya pemahaman para aparat penegak

\footnotetext{
${ }^{31}$ Ibid.

${ }^{32}$ Ibid., hlm. 462.
} 
hukum akan menimbulkan tatanan yang terbentuk dalam satu kesatuan sistem hukum nasional akan menyimpang dari pada arah tujuan politik hukum. Perlunya penegakan hukum yang jelas bagi para pelaku/perusak lingkungan hidup agar menimbulkan efek jera dan di antara 3 sanksi (pidana, perdata dan administrasi) tersebut tidak adanya tumpang tindih. Penegakan hukum sulit dilakukan oleh karena sulitnya pembuktian dan menentukan kriteria baku tentang kerusakan lingkungan.

\section{Daftar Pustaka}

\section{A. Buku:}

Keraf, A. Sonny, 2010, Etika Lingkungan Hidup, Jakarta: Kompas.

Nusantara, Abdul Hakim G., 1988, Politik Hukum Indonesia, Jakarta: Yayasan Lembaga Bantuan Hukum Indonesia Cetakan Pertama.

Prasetio, Adi, 2009, Good Governance dan Pembangunan Berkelanjutan; Meretas Pemikiran Naya: 37 Tahun Masa Pengabdian Prof. Suma Tjahja Djajadiningrat, Ph.D. Bandung: ICSD \& SDM ITB.

Mohammad, Askin, 2008, Hukum Lingkungan, Jakarta: Penerbit Yayasan Peduli Energi Indonesia (YPEI).

Kairsy, David, 1990, The Politics of Law, A Progressive Critique, New York: Pantheon Books.

MD, Mahfud, 1998, Politik Hukum di Indonesia, Jakarta: LP3ES.

Mujibussalim, 2008, Perlindungan Hukum Terhadap Sumber Daya Alam

Berkaitan Dengan Peraturan Perlindungan Hutan Dalam Pelaksanaan Otonomi Daerah, Disertasi, Bandung: Universitas Padjadjaran.

Rosadi, Otong dan Desmon, Andi, 2013, Studi Politik Hukum: Suatu Optik Politik Hukum, Edisi II, Yogyakarta: PT. Thafa Media.

Penjelasan Umum 1, Undang-Undang Nomor 32 Tahun 2009 Tentang Perlindungan dan Pengelolaan Lingkungan Hidup

Rahardjo, Satjipto, 2009, Hukum dan Perubahan Sosial, Yogyakarta: Genta Publishing.

Rangkuti, Siti Sundari, 1996, Hukum Lingkungan dan Kebijakan Nasional, Surabaya: Airlangga University Press.

Rahmadi, Takdir, 2014, Hukum Lingkungan Di Indonesia, Jakarta: Raja Grafindo.

\section{B. Lain-lain:}

Absori, 2005, Penegakan Hukum Lingkungan Pada Era Reformasi, artikel dalam Jurnal Ilmu Hukum, Vol. 8. No. 2 
Sutrisno, 2011, Politik Perlindungan dan Pengelolaan Lingkungan Hidup, Jurnal Hukum No. 3 Volume 18

Siti Kotijah, 2011, Evaluasi Undang-Undang Nomor 32 Tahun 2009, 2009, Jurnal Hukum No 2 Volume 18

Teuku Muhammad Radhie dalam majalah PRISMA, no. 6 tahun keI-II, Desember 1973 